EUROPEAN UNIVERSITY INSTITUTE, FLORENCE

DEPARTMENT OF POLITICAL AND SOCIAL SCIENCES

EUI Working Paper SPS No. 99/2

The Machiavellian Legacy:

Origin and Outcomes of the Conflict

Between Politics and Morality in Modernity

Miguel E. VATTER

BADIA FIESOLANA, SAN DOMENICO (FI) 
All rights reserved.

No part of this paper may be reproduced in any form without permission of the author.

(C) 1999 M.E. Vatter

Printed in Italy in May 1999

European University Institute

Badia Fiesolana

I - 50016 San Domenico (FI)

Italy 


\title{
THE MACHIAVELLIAN LEGACY: ORIGIN AND OUTCOMES OF THE CONFLICT BETWEEN POLITICS AND MORALITY IN MODERNITY
}

\author{
Miguel E. Vatter \\ Department of Political and Social Sciences \\ European University Institute
}

"Il nome della libertà, il quale forza alcuno non doma, tempo alcuno non consuma e merito alcuno non contrappesa."

Machiavelli, Istorie Fiorentine, II 34

"It is true that we have to give up hope of ever acceding to a point of view that could give us access to any complete and definitive knowledge of what may constitute our historical limits. And from this point of view the theoretical and practical experience that we have of our limits and of the possibility of moving beyond them is always limited and determined; thus we are always in the position of beginning again."

Foucault, What is Enlightenment? 
The disputed nature of Machiavelli's legacy

The purpose of this essay is to offer a new description of Machiavelli's legacy to the political and philosophical discourse of modernity. I take as my starting point Strauss's interpretation of this legacy because he proposes its strongest version, one which is adopted, in its central points, even by thinkers who wish to defend, rather than reject, the project of modernity. Put bluntly, Strauss argues that modern political thought, from Machiavelli and Hobbes, through Rousseau, Kant and Hegel, culminating in Nietzsche, is thoroughly historicist, ${ }^{1}$ by which he means that it cannot "answer the question of right and wrong or of the best social order in a universally valid manner, in a manner valid for all historical epochs, as political philosophy requires.",2

Strauss takes Machiavelli to be responsible for modern historicism on the basis of the following, central argument:

classical political science took its bearing by man's perfection or by how men ought to live, and it culminated in the description of the best political order. Such an order was meant to be one whose realization was possible without a miraculous or nonmiraculous change in human nature, but its realization was not considered probable, because it was thought to depend on chance. Machiavelli attacks this view both by demanding that one should take one's bearings, not by how men ought to live but by how they actually live, and by suggesting that chance could or should be controlled. It is this attack which laid the foundation for all specifically modern thought. The concern with a guarantee for the realization of the "ideal" led to both a lowering of the standards of political life and to the 
emergence of "philosophy of history": even the modern opponents of Machiavelli could not restore the sober view of the classics regarding the relation of "ideal" and "reality."3

According to this schema, the ancients are "idealist" because they uphold the absolute, non-mediatable separation or chorismos between fact and norm, real and ideal, is and ought, while the moderns are "realist" because for them this separation is relative and allows for mediation. Given the absolute character of the separation between real and ideal, the ideal can realize itself in the real only "by chance," in the sense that there is no "reason" or "ground" that can bridge the chorismos between the ideality of the good and the facticity of the real. Conversely, the relative character of the separation between fact and norm, real and ideal, opens the way for thinking of a rational process whereby one can be realized or unified in the other at the cost of "lowering" the standards of what counts as virtue. In order for the ideal to be realized in the real (or conversely, for the real to be raised to the ideal), one must add the further requirement that human action be capable of controlling chance through a technical conception of reason, that is, a conception of reason that allows to "master" the irrationality, the contingency or chance-character of the real. It is easy to see why Strauss concludes that by setting forward these two requirements, Machiavelli's discourse originates modern philosophy of history (whose central tenet is best captured by Hegel's dictum that "the rational is the real, 
and the real is the rational") ${ }^{4}$, while at the same time it reduces "the political problem... [to] a technical problem" thanks to its instrumentalization of reason. ${ }^{5}$

Behind this loss of absolute moral standards and the rise of instrumental rationality stands modernity's rejection of heteronomy: "man calls nature before the tribunal of his reason... all truth and meaning originate in man; they are not inherent in a cosmic order which exists independently of man's activity." ${ }^{6}$ In particular, modern thought destroys the teleological understanding of nature according to which "there is a specific perfection which belongs to each specific nature.... [and] nature supplies the standard, a standard wholly independent of man's will."7 Prior to modernity, according to Strauss, both "Athens" and "Jerusalem" coincided in proclaiming the heteronomous ground of morality, where the secondary place held by human beings in the order of things was unquestioned. For the Bible, righteousness is compliance with the "divinely established order;" for Greek and Roman thought, justice "is compliance with the natural order." ${ }^{\text {M }}$ Modern political thinking, instead, emerges once both the divine ("Jerusalem") and the natural (“Athens") foundations of order are brought into question.

Strauss's reconstruction of modernity is not easily brushed away. In its essentials, it corresponds to Blumenberg's understanding of modernity in terms of the "self-assertion" of man, which he takes to mean "an existential program, according to which man posits his existence in a historical situation and indicates to 
himself how he is going to deal with the reality surrounding him and what use he will make of the possibilities that are open to him."9 Strauss's claim that the modernity initiated by Machiavelli finds its completion with Nietzsche is echoed by Blumenberg saying that the modern "existential program" finds its fullest expression in Nietzsche's concept of the eternal return, which he interprets as the attempt "to raise the sum total of consequences of human action to the role of the ineluctible lawfulness of the world and thus to charge man with absolute responsibility for the world. Theory, which contemplates the world, was to become functionless compared with the praxis that changes it." ${ }^{10}$ But whereas Blumenberg does not venture into why the priority of praxis over theory, the effort to change given orders of things as opposed to the contemplation of an eternal order, should require the critique of the moral viewpoint and the radical negation of the difference between ideality and reality that one finds in Nietzsche, Strauss instead sees a direct connection between human self-assertion and the progress of nihilism and relativism in modernity.

If, as Strauss argues, human autonomy or self-assertion (for the moment I do not distinguish these variations on the fundamental priority of praxis over theory) is bought at the price of denying the absolute transcendence of the ideal (the normative) over the real (the factual), then morality is necessarily relativized with respect to the political attainment of human autonomy, bringing politics and morality 
inevitably into conflict, and opening the way to relativism. ${ }^{11}$ Furthermore, because human autonomy loses the sense of the absolute difference between is and ought, means and ends, modern rationality inevitably tends to privilege instrumental or technical reason at the expense of value rationality (to use Weberian terms), leading in the short run to the loss of value on the part of the highest values (i.e., to nihilism) or, in the historicist formulation favored by Strauss, to the historical situatedness of all validity claims.

Strauss's diagnosis issues a devastating and hardly avoidable challenge: if the modern project of human self-assertion necessarily leads to "historicism," "nihilism," and "relativism," then this project must be abandoned, and the priority of morality over politics reasserted by returning to the traditions of classical rationalism (“Athens" and "Jersualem"). I propose to accept Strauss's challenge and defend the claim that the commitment to freedom in modernity requires the political and historical situatedness of morality. For the "lowering" of moral standards that Strauss condemns corresponds to the "elevation" of freedom in human affairs, first evidenced by Machiavelli's understanding of self-assertion as political virtù. Nihilism, relativism and historicism, under the redescription that I offer of them, appear as features of an extra-moral ethics of responsibility in the face of the "heightened" demands of human freedom, rather than as symptoms of a willful immorality on the part of the moderns (as Strauss sees it). This commitment to 
freedom, this requirement of the relativity of the moral, and finally this ethics of responsibility in the face of both the commitment and the requirement compose what I call the Machiavellian legacy to modernity.

There exists a competing legacy in modernity, generally identified with the discourse of Kant, that also assumes the central role of freedom as self-assertion, while holding that this freedom is in the last instance identical to moral autonomy, not political virtù. The proponents of the Kantian legacy share many of Strauss's criticisms against modernity but they do not want to adduce the responsibility for its slippages into relativism or historicism or nihilism on the centrality of freedom as such. Luc Ferry's neo-Kantian critique of modernity, for example, is in agreement with Strauss on two counts, namely, that modernity runs the risk of falling into historicism, and that Machiavelli and Hobbes are responsible for allowing this risk to emerge in modernity. ${ }^{12}$ But Ferry rejects Strauss's reduction of modernity to the purportedly "naturalistic" bases first established by Machiavelli and Hobbes. According to Ferry, modernity escapes historicism by grounding the absolute character of the distinction between fact and norm on a non-naturalistic, transcendental concept of human freedom as moral autonomy (in accordance with the doctrines of Rousseau, Kant and Fichte). ${ }^{13}$ If Strauss ultimately thinks of modernity as having exchanged history for nature as the standard of values, making all values both historical and subjective and thereby, in the end, depriving them of 
value, Ferry responds by pointing out that Strauss may be right with regard to Machiavelli, Hobbes or Nietzsche (who are charged with considering only different kinds of "self-interested" freedom), but that his argument fails in the case of Kant, for whom there is a moral conception of freedom which escapes the charge of nihilism and historicism. Modern political philosophy can make place for a philosophy of history without thereby falling into historicism, since, in the thought of Kant and Fichte, it is precisely the transcendence of the ideal over the real, on the basis of a concept of noumenal freedom and not of a teleological idea of natural order, that accounts for historical progress. ${ }^{14}$

Similarly, in his analysis of the origins of modern political philosophy, Habermas reproposes the charge that Machiavelli is responsible for reducing politics to a technique of power and for bringing instrumental reason into the sphere of morality: "what is modern [in Machiavelli/MV] is the thesis that the technically appropiate organization to meet the necessities of life, the correct institutional reproduction of society, is prior to the good life, without these in themselves representing the content and the goal of moral action." ${ }^{15}$ But, unlike Strauss, Habermas entertains the possibility that the introduction of instrumental rationality into politics, intended to master the necessities of social life, might itself come under the control of "moral action," where morality does not refer to the ancient doctrine of virtue but rather to the modern theory of autonomy. Habermas predicates the possibility of 
recomposing the conflict between politics and morality in modernity on the capacity of moral autonomy to avoid the twin rocks of ancient dogmatism and modern relativism.

If modernity effects a massive break with the belief that human praxis ought to be oriented towards the compliance with a heteronomous normative order, as Strauss and Blumenberg and Habermas all agree, it remains to be seen what kind of question modernity brings to bear on the instance of order from its new perspective of the autonomy of human praxis. On this point there seem to be only two possible options: either modernity, like previous epochs, seeks in this autonomy a new foundation of moral order, or modernity, unlike previous epochs, questions the primacy of moral order in the name of freedom, and sees an irreconcilable tension between the claims of freedom and those of morality.

Strauss and Habermas opt for the first reading of modernity. But Strauss takes the position that once the difference between fact and norm, real and ideal, is not founded on a pre-given and unchangeable (natural or divine) order, but exists only in so far as man makes it himself, then there is no stopping the decline from moral constructivism to moral relativism. Habermas, on the contrary, believes that freedom as autonomy has an inherent relation to order such that it can realize itself only if it gives itself the form of law, that is, if it checks itself by itself. This noumenal or rational conception of freedom gives rise to a concept of history as the process 
whereby the real is progressively rationalized, that is, transcended and changed for the sake of the ideal (e.g., some variation of the Kantian kingdom of ends) and the ideal in turn acquires its validity through its progressive realization in the real. Norm and fact, validity and facticity, enter into a dialectical relation that enables both terms. ${ }^{16}$ In this way, freedom and justice, politics and morality, are seen to be in principle compatible. For this strategy, then, freedom functions as the ground of a new morality in modernity. If it makes impossible the kind of heteronomous morality that Strauss identifies with the pure types of "Athens" and "Jersualem," nonetheless it purveys a morality and serves to legitimate social and political order: the question of "the best social order" is still answered "in a universally valid manner," except that the answer now calls for the "priority of the right over the good," in Rawls's famous formulation.

The Machiavellian legacy opts for the second reading of modernity. It sees in the modern dissolution of ethical substance or moral order the effect of the emergence of a radical conception of freedom as no-rule that resists the reduction of political life to establishing legitimate forms of domination. This legacy develops a discourse on freedom that emphasizes its facticity. Facticity denotes that aspect or aspects of experience that function as the unconditioned condition of any theoretical determination of experience. This understanding of "facticity" is usually opposed to the idea of "validity," which assumes that only rational or theoretical 
determinations provide the unconditioned condition of experience. Therefore "facticity" is to be strictly distinguished from "factuality" or the state of being a “fact." Modern philosophy, at least since Kant's Copernican revolution, advances the belief that theories are underdetermined by facts, and, furthermore, there are no facts without some theory that makes them possible as facts. But if there are no facts without theory, one cannot say the same about facticity: mortality and temporality (both of which cannot be experienced as facts or objects of experience, and yet without which one would have no such thing as experience) are examples of factical, as opposed to factual, conditions of human life. ${ }^{17}$

In speaking about the facticity of freedom my intention is to bring out two of its traits that are assumed without much analysis in both Strauss's and Blumenberg's discussions of modern self-assertion. The first trait is the historical situatedness of human freedom, whereby "man posits his existence in a historical situation and indicates to himself how he is going to deal with the reality surrounding him," to use Blumenberg's words. The second trait is the understanding of this freedom in terms of the priority of praxis over theory, whereby changing the orders of the world becomes more important than contemplating them. Freedom is factical both in the sense that it is historically situated and that it can transcend its situation by changing it. The two aspects of Machiavelli's discourse that Strauss builds on for his theory of modernity, namely, the "realism" of Machiavellian politics and its claim to 
"master chance," correspond to the two traits of the facticity of freedom. My claim is that the "historicism," "nihilism," and "relativism" evoked by Strauss's analysis of self-assertion acquire new meaning once they are understood as attributes of the factical conception of freedom. Here I briefly introduce this semantic change, in order to develop it below.

The historical situation of factical freedom is linked to the new meaning of historicism in the following way. The difference between necessity and contingency is situated rhizomatically in events, rather than grounded in forms; this means that the difference between necessity and contingency (and consequently the difference between ideal and real, validity and fact) is itself contingent or revocable. Historicism is redefined by the space of this revocability of modalities; and factical freedom can subsequently be defined in terms of the power or virtù to change its situation by revoking the contingent into the necessary and the necessary into the contingent. This revocability of modalities defines an action as capable of changing its situation, and therefore as free in the required sense. Analogously, Strauss's claim that Machiavelli's discourse denies all natural teleology in favor of chance can now be reinterpreted to mean that all determinations of necessity emerge historically. This entails that the capacity to "master" chance, which Strauss identifies as the clarion call of instrumental rationality, can also be reinterpreted to mean that the historical situation in which necessity is determined can itself be 
changed through ethico-political sollicitation, thereby revoking the necessary back into the contingent and in so doing "giving rise to the risk of an even greater chance, ${ }^{, 18}$ rather than to the technical extirpation of chance.

The capacity to factically transcend its situation exhibited by this conception of freedom is linked to a redescription of nihilism as follows. Virtù or factical freedom is the movement of transcendence of reality: virtù is that through which an objective or legitimate order of things can be virtualized, i.e., can have its foundation or essence withdrawn and be reduced to mere appearance, semblance or ideology. This transcendence of freedom is factical in the sense that it exceeds the horizon represented by the unity between the real and the ideal, fact and norm. From the perspective of factical freedom, this unity reveals itself as being functional to the imposition on human praxis of necessary conditions of possibility that grant it its objective form. As Habermas says, "the counterfactual presuppositions of actors who orient their action to validity claims also aquire immediate relevance for the construction and preservation of social orders; for these orders exist through the recognition of normative validity claims." ${ }^{, 19}$ The objective forms of human praxis are simply products of the legitimation of the real, of the construction of moral order. If there is to be an effective transcendence of objective reality, if a change of situation is truly conceivable, then this transcendence cannot be oriented toward the ideal, it cannot come as a function of the determination of a rule or norm, for the latter 
always underpins the construction of objectivity, but it will rather be oriented toward "nothing," toward the peculiar, non-dialectical negativity that I have identified as no-rule. In this sense, then, one can speak of the "nihilistic" attribute of factical freedom.

If the commensurability between politics and morality, freedom and justice, is a requisite for the construction of legitimate order, then the contestation, resistance and revocation of every such order depends on the possibility of articulating certain moments of incommensurability between freedom and justice, morality and politics. The "immoralism" that Strauss identifies in Machiavelli's discourse can therefore be reinterpreted in terms of such an incommensurability between factical freedom and the discourse of morality. Likewise, the "realism" of Machiavelli's discourse can now be reinterpreted to mean two things simultaneously: on the one hand, the attention brought to the ways in which the transcendence of the ideal over the real, of the validity of the norm over the factual situation of its applicability, not only does not imperil the establishment of political and social order but is necessary for such a purpose. And, on the other hand, that only the factical character of the transcendence of human freedom, i.e., the capacity of freedom to transcend an objective state of affairs without being determined to do so by a norm or rule, can guarantee the possibility of changing objective reality in events of no-rule. 
Machiavelli's "realism" is therefore a realism about freedom in its insurmountable tension with the project of establishing fixed orders.

In the alternative reading of modernity proposed by the Kantian legacy, the factical concept of freedom is reductively understood as a particularistic shape of modern self-assertion that can be either subsumed, neutralized or excluded by the understanding of freedom as moral autonomy. ${ }^{20}$ I suggest that this move not only betrays a lacks of historical sense, but is also philosophically problematic. Such a reading of freedom in modernity forgets, as Strauss insightfully points out, that the Kantian or constructivist understanding of freedom rises on a terrain, a situation, that is prepared by the fact that "Machiavelli had completely severed the connection between politics and natural law or natural right, i.e., with justice understood as something independent of human arbitrariness. The Machiavellian revolution acquired its full force only when that connection was restored: when justice, as natural right, was reinterpreted in Machiavelli's spirit. This was the work primarily of Hobbes." ${ }^{21}$ Needless to say, Kant and Hegel follow Hobbes in the attempt to reconnect politics and natural right in the situation of modernity characterized by a radical caesura between the discourse of freedom (politics) and that of justice (morality). Strauss's insight is interesting because of the suggestion that Machiavelli's discourse operates this caesura in advance of the elaborations of this situation by the moral constructivisms of both a Hobbes and a Kant that "re-occupy" 
(to employ Blumenberg's term) the positions left open by classical natural right, and does so not only without providing the foundation for the emergence of a new doctrine of natural right, but, more importantly, by showing the questionableness of just such a foundational project.

The attempt to sublate Machiavellian, factical freedom under Kantian, noumenal freedom is also philosophically problematic because, were this operation to succeed, it would unwittingly undermine the very conception of freedom it seeks to uphold and universalize. In suspending the the claim to necessary and universal validity congenital to the discourse of morality, the idea of factical freedom opens itself to self-contestation and plurality, which is in turn pragmatically embodied by the other, moral conception of modern freedom. The absence of legitimacy or foundation for the factical conception of freedom is, in the end, the very trait that does not disallow for the noumenal conception of freedom as foundation for legitimacy, all the time limiting its univocal claims in the name of that selfcontesting and self-differing understanding of freedom that allows them to maintain their conflictual cohabitation in the discourse of modernity. This is the sense in which one can say that relativism is a feature of the Machiavellian legacy to modern freedom. 
The conflict between politics and morality in modernity

Machiavelli is the first to formulate the conflict between politics and morality as an unsurpassable feature of the human condition. ${ }^{22}$

Many have imagined states such as nobody ever saw or knew in the real world, and there is such a difference between the way we live and the way we ought to live that the man who neglects the real to study the ideal will learn how to accomplish his ruin, not his salvation. Any man who tries to be good all the time is bound to come to ruin among the great number who are not good. Hence a prince who wants to keep his authority must learn how not to be good. ${ }^{23}$

Political life no longer aims towards the moral ideal of a good life but is now turned towards "the way we live," that is, to factical life, where not everyone is good all the time. Once political life loses its internal reference to the good life, the state (the prince) reveals itself as a political actor that knows how not be good in its employment of violence and conflict to achieve its political rule. But this outcome is neither the first, nor the most significant result of Machiavelli's re-evaluation of the facticity of the human condition. For this outcome presupposes that one cannot be good all of the time, one cannot actually live "the good life" without thereby ceasing to live life as it is given, in its facticity. ${ }^{24}$ For Machiavelli goodness is a possibility that is situated in time: there is a time to be good, but one cannot be good all the time. This claim raises the question: what political aspect or aspects of factical life determine that one cannot be good all the time? 
The conflict between politics and morality runs through modern political thought like a red thread. No serious thinker has escaped it, though many have tried to pacify it. So it is that Hobbes denies that there can be a difference between despotism and monarchy, i.e., between factical and legitimate domination, in a political system whose goal is the equal protection of every individual's free pursuit of their factical life. For Kant the institution of a state based on the political freedom and equality of its members is a problem that "can be solved even by a nation of devils." Indeed, this problem can only be solved by devilish human beings because the solution requires the conflict between self-interested individuals "in such a way that their self-seeking energies are opposed to one another, each thereby neutralising or eliminating the destructive effects of the rest." ${ }^{, 5}$ Hegel constructs his system of right by relying on the "cunning of reason" working in history. This cunning is manifest in the verdicts of the tribunal of history which pursues the development of freedom "by any means necessary," and in so doing continuously humiliates the individual's moral conscience. Weber inaugurates contemporary political thought by rejecting an ethics of ultimate ends in favor of an ethics of responsibility, which corresponds to his belief that modern life is characterized by a polytheism of values, none of which can be demonstratively shown to be more legitimate than the rest. As a consequence, legitimacy must be grounded on a value-free (neutral) and procedural idea of legality, which can be applied on condition that the state hold the 
monopoly of violence. In short, for Weber legitimacy and violence have an internal relation. After Weber's collapse of legitimacy onto legality, two general strategies have recently emerged to respond to this situation. The first, associated with Habermas, attempts to recover the Kantian legacy from within the scenario revived by Weber. Habermas seeks to answer the question of "how legitimacy is possible on the basis of legality" ${ }^{26}$ by pursuing the possibility that the factical dimension of politics has an essential relation to the moral validity of the law. ${ }^{27}$ The second strategy, associated with Foucault, pursues the Machiavellian legacy that sees legal and moral order as a function of a conflict between practices of domination and moments of resistance..$^{28}$

In spite of the massive differences between these positions, none of them formulate the moral point of view without taking into consideration, as a fundamental given, that the extra-moral aspects of political life have an essential relation to the facticity of freedom. In modern political thought the moral point of view, no matter how it is articulated, depends on the assumption that political freedom has priority in the factical life of human beings. No modern discourse on justice can afford to speak against the assumption that political freedom is a factical condition of life.

But the decisive consideration is that freedom does not stand in a symmetrical situation with respect to morality: not only does political freedom not rest on 
morality, but it does not even assume itself as a normative principle. In the former sense, political freedom is factical, not normative, because there is no one way in which freedom "ought" to exist. In the latter sense, political freedom is factical because it exists by contesting its meaning. Freedom is political to the extent that it is free to interpret itself.

Modern political freedom situates or relativizes the claims of morality, and is in this sense extra-moral. But political freedom is not extra-moral in any one particular sense: there are only extra-moral senses of freedom, as I illustrate below. The point of drawing out these outcomes is to show the futility of passing a moral judgment on these senses of freedom, and hence the need to maintain the conflict of politics over morality. One cannot ask of them "which is (morally) better" without bringing into question the very equivocity of meaning that is essential to the selfunderstanding of political freedom in modernity. Put otherwise, to lead a free political life in modernity it is not sufficient not to be good, it is not enough to dwell with the conflict between politics and morality. One must also learn how not to be good, which means to learn how to dwell with the further, inevitable conflict of interpretations about that conflict. The latter task defines the purpose of an ethics of responsibility in the modern situation. 
The unity of politics and morality in the ancients

How the moderns ended up in this situation can be traced out by working through the charges that Strauss advances against Machiavelli. The first of these is Machiavelli's "lowering" of standards for virtue entailed in his belief that political virtue requires "learning not to be good." Strauss takes this claim to mean that virtue is no longer "understood as that for the sake of which the commonwealth exists, but virtue exists exclusively for the sake of the commonwealth; political life proper is not subject to morality... [because] it presupposes political society." ${ }^{29}$ As a consequence, the priority assigned to political goals relativizes the scope of morality: political life is neither instrumental nor consubstantial to the achievement of the good life, the state is no longer the ethical substance it was for the ancients.

But it is Machiavelli's second thesis that definitively cuts the moderns off from the ancients and decides their trajectory:

fortuna (chance) is a woman: and it is necessary, if one wishes to keep her down, to beat and hit her. And one sees that she lets herself be won more by the impetuous than by those who proceed coldly; and always, like a woman, she is the friend of youth, because they are less respectful, more ferocious, and have more audacity to command her. ${ }^{30}$

In his intentionally shocking formula, Machiavelli posits the conflictual, violent relation that holds between chance and political action. Strauss contrasts this belief with that of classical political philosophy for which "the establishment of the best 
regime depends necessarily on uncontrollable, elusive fortuna or chance." ${ }^{31}$ In other words, whereas for the moderns political virtue is in conflict with chance, for the ancients moral virtue stands in harmony with chance.

The best regime is said to depend on chance because the moral standard against which any political regime must be measured is at once ideal and absolute: there is an absolute separation (chorismos) between fact and norm, is and ought. ${ }^{32}$ As a consequence, there can be no rational or logical calculation $(\log o s)$ of means and ends that can bridge the abyss between the validity of the good (the sphere of intelligible form) and the facticity of the real (the sphere of material circumstances, of historical situations). This is why Plato says that the ideal can realize itself in the real only by a providential "chance," if at all; this is why Aristotle claims that the moral virtues, as practical dispositions to choose the mean, presuppose the existence of contingent situations over which these virtues have no control. ${ }^{33}$

The absolute separation between validity and facticity to which Strauss draws attention is another way of asserting that the good is in no way situated or dependent on the given, factical situation. This in turn means that irrespective of the situation it is always possible, as a matter of principle, to "do the right thing," since "what is right" is independent of each and every situation. "What is right" is determined "by nature," not by historical convention. Because there is, in principle and as a matter of principle, a right and a wrong way for everything that happens 
the order of nature is said to be teleological. Human beings cannot willfully do as they please, they cannot willfully disregard the natural rule, without incurring into some wrong, as tragic wisdom (here at one with Platonic thinking) teaches. From these assumptions, Strauss draws out two basic points of ancient moral teaching. The first is that "man's power is limited [and] this limitation shows itself in particular in the ineluctible power of chance." The second is that "nature supplies the standard, a standard wholly independent of man's will" and "the good life is the life according to nature, which means to stay within certain limits: virtue is essentially moderation., ${ }^{, 34}$ But if Strauss shows that for the ancients there obtains a fundamental correspondence between virtue oriented toward the good and the respect of chance, he tends to pass over a point of decisive political importance, namely, that the belief in a natural teleology, the belief that the good commands in nature, quickly translates into the double proposition that goodness consists in ruling according to nature, and that the "best order" [ariste politeion] is the one in which the "good" individuals [spoudaios] may rule. Together these propositions account for the aristocratic bias of classical political thought.

The limit imposed to human freedom and power by ancient ethics is simply the expression of the fundamental belief that the natural division between ruler and ruled is good as such and, conversely, that the good life is a matter of ruling and being ruled. ${ }^{35}$ When Aristotle states that "excellence [arete] must be the care of the 
state" he points to this deep affinity between politics and morality, between the practice of rule and the practice of virtue, contained in the idea of the political state as an ethical substance. ${ }^{36}$

This idea of ethical substance can also be deduced from the respect for chance. Chance functions as a cipher of the idea that the good is absolutely transcendent with respect to the situation. ${ }^{37}$ This transcendence allows for every action, as a matter of principle, to aim at the good in any given situation. Since the good is ideal and can therefore be kept in view only theoretically (nous or techne in Plato, phronesis in Aristotle), and theory is fundamentally a question of homologating the soul to the natural order, it follows that the action will be good to the extent that it is "adequate to," or "matches with," or "corresponds to" the situation, where the situation is always already determined as a case of a possible law, as an instantiation of the natural order. "To do the right thing at the right time" is the moral ideal of the ancients. ${ }^{38}$

Since virtuous action must correspond to the situation it cannot have as its aim to change the situation. By default all normative action tends to fixate the historical situation into an unchangeable order, i.e., into a natural substance. Political action, in so far as it is in harmony with moral virtue, is done in view of order and therefore political life condenses into the political substance of the state. Furthermore, if normative action exists in view of order, then it must not bring about 
conflict. For the ancients, virtuous action must seek concord; it is essentially moderate. The evolution of the political situation into a political substance coincides with the becoming-moderate or becoming-prudent of political action. It is in this sense that the political substance becomes an ethical substance.

The fundamental affinity between action and chance in ancient political thought leads to the idea of the state as ethical substance. This idea expresses the dialectical relation that holds between the practice of the good and the practice of ruling. When the ethical good rules over action (by aiming for concord and moderation) then the political rule is good, in the sense that the regime acquires stability and expands its dominion, leaving it less vulnerable to unexpected change of situations, just as if its historical and contingent encounters were guided by providence. Conversely, the political rule that seeks to stabilize itself will call forth actions that acquire their ethical character by corresponding to their situation, rather than changing it. This schema expresses the fundamental unity between politics and morality in the ancients from Plato and Aristotle to Polybius and Cicero. 
The discordant origin of modern political freedom

Returning to Machiavelli's formula that "chance is a woman, and it is necessary, if one wishes to keep her down, to beat her," it is clear that by positing an irreconcilable conflict between political action and its historical, contingent circumstances, between virtue and chance, Machiavelli sets the basis for the dissolution of ethical substance in modernity. The disrespect for "elusive chance" on the part of human virtù thus entails a wholesale rejection of the most basic assumption made by ancient political thought, namely, that rule is good and that the good is a matter of rule. The conflict between politics and morality introduced by Machiavelli's discourse really amounts to the denial that the activity of rule can have an apriori or metaphysical justification or legitimation. Because this discourse rejects the idea that domination can ever be a good, it is in a position to expose the violent, strategic establishment of systems of legal domination along with their normative underpinnings. In short, as Spinoza and Rousseau knew, Machiavelli's discourse is scandalous only for those who wish to reduce political life to the activity of dominating others in a legitimate way.

The logic of Machiavelli's argument can be reviewed as a function of the reversal of the premisses that previously lead me to the idea of ethical substance. The new idea of a conflict between virtuous action and chance entails the rejection 
of the premise that the good transcends every situation. In Machiavelli's discourse the good is always situated. Eventually the good life becomes a matter of individual perspective and ceases to be as such a political question. Once the good is situated, human action no longer has to correspond to its situation, and political action becomes defined by the capacity of human action to engage, and be a match for, its circumstances. The freedom of human action is not limited to the prudent goal of corresponding to its situation but is defined in terms of its power (virtù) to change its situation. Machiavelli establishes an internal relation between human freedom and historical situation which can best be described by the formula: human freedom is always in a situation to be able to change its situation. This is the effective meaning of Machiavelli's formula "fortuna is a woman."

The new situation in which morality finds itself is "political, not metaphysical" (to cite Rawls): it responds to the political practices of freedom and power, not to the normative metaphysics of rule of the ancients. But in the name of what does Machiavelli relativize the good or the just? For the ancients the end of morality is the constitution of an ethical substance, that is, the establishment of an internal relation between the practice of rule and the practice of the good. Therefore, by situating the good Machiavelli relativizes the practice of rule in political life. The practice of rule can only be relativized with respect to an instance of no-rule (anarchy). 
Machiavelli's critique of the unity of morality and politics turns around the new idea of political freedom as no-rule, as suspension of the command-obey relation, as absence of legitimate domination. As he says, "if one considers the end of the nobles and of the people, one will see in the former a great desire to dominate and in the latter only the desire not to be dominated, and thus a greater will to live freely." 39 The "people" are not a unitary substance; this term stands for all those who find their motive for action simply in the desire not to be dominated or oppressed. Conversely, the "nobles" are simply those who find their motive for action in the desire to dominate. From the new perspective introduced by the desire for no-rule, Machiavelli can show that political life does not reduce itself to the problem of "who ought to rule." Political life steps outside of the mythical circle between the practice of rule and the practice of the good within which ancient thought had constrained it. Political life becomes dialogical by having to determine "who ought to rule" in a situation that allows the desire for no-rule to be voiced by those who are dominated in any given political order. As a consequence, after Machiavelli the question of political freedom in modernity ceases being the classical one of establishing and maintaining the best political form of rule, but instead becomes that of knowing how to change political forms in order to respond to the ever renewed, and never satisfied, demands for freedom as absence of oppression. 
The concept of political freedom as no-rule can decenter the moral point of view because it has no internal relation to the sphere of justice. One can illustrate this point by taking Kant as an example, the one modern thinker everyone would put forward as a counterexample to my claim. It has not been pointed out enough that in Kant there is a primordial separation between freedom and justice:

Rightful (i.e. external) freedom cannot, as is usually thought, be defined as a warrant to do whatever one wishes unless it means doing injustice to others [because]... the definition would run as follows: freedom is the possibility of acting in ways which do no injustice to others. Thus the definition is an empty tautology. In fact, my external and rightful freedom should be defined as a warrant to obey no external laws except those to which I have been able to give my own consent. ${ }^{40}$

Here freedom is not defined through an internal relation to justice, but rather through its negation of rule: "a warrant to obey no external laws except those to which I have been able to give my own consent." External freedom is understood in relation to non-obedience of any external authority, first, and only secondly as obedience to one's autonomy, i.e., obedience only to the law one has given to oneself. But to give oneself the law of one's action, as the Groundwork of a Metaphysics of Morals shows, means to be free internally. Thus also the second part of the definition of external freedom does not contradict the idea of no-rule, since external freedom ends up signifying: non-obedience to any source of external rule, and obedience to an internal source of freedom. In a second moment, external freedom is tied to coercion: this connection gives the idea of "right" as "rightful" freedom. Only here, when freedom as no-rule is tied to coercion (and so to domination) does one have 
the return of the discourse of justice, something that is reflected by the fact that one is speaking of freedom as "right."

The connection between freedom as no-rule and coercion which leads to the idea of freedom as right requires the introduction of the concept of equality. But there are at least two pertinent senses of equality to be considered. The first springs from the idea of freedom as no-rule: it is an expression of the factical situation that, since freedom as no-rule cannot coerce anyone, so everyone is free to be "free," i.e., to give oneself the law; and in this sense only is everyone "equal." Therefore the originary idea of equality also has nothing to do with justice, but merely follows from the inner logic of freedom as no-rule. Freedom and equality together define the possibility of justice, not vice versa: to be just means to act in the respect of the freedom and equality of everyone. Since this respect entails the freedom of an other, and so a check to my freedom, but since freedom cannot, as such, be checked, the check will be in the form of coercion. The unity of justice and coercion on the foundation of freedom as no-rule gives external or rightful freedom. Thus freedom, both internally and externally considered, is always already "political" in Kant: in the sense that it has to do with the priority of the rule/no-rule opposition.

Returning to the main argument in Machiavelli's discourse, since political freedom has no internal relation to justice, one can say that political action no longer presupposes concord as its final cause. On the contrary, the category of discord 
becomes fundamental to political action. In particular, what is fundamental for the political situation in which morality finds itself is the discord between those who want to rule and those who want no-rule. For Machiavelli, no-rule is linked to the entrance of "the people that desires not to be commanded or oppressed" into political life. ${ }^{41}$ Strictly speaking, it is questionable to say that modern politics has a "democratic" bias, in the sense of a bias towards the rule by the people. Rather, one should say that the Machiavellian legacy imparts to modern politics a "republican" bias, in the sense of a bias directed to the empowerment of the people in order to resist and topple forms of political and social oppression.

It is particularly important to recognize that modern freedom is, first and foremost, conceived as no-rule, and therefore it is primarily opposed to domination or rule. In Machiavelli's discourse, and I believe for the rest of modern political thought as well, the desire to rule and the desire for freedom as no-rule are the basic givens of human factical life. Justice is not such a given. The discourse of justice is secondary with respect to the above opposition, and it is related to the problem of who is to rule. Justice has an internal relation to rule, not to no-rule: it is only from within the logical space of ruling and being ruled that it makes sense to ask whether something, namely the type of command or the type of obedience, is just. One cannot ask whether the demand for freedom as absence of domination is just. Justice is a matter of setting limits to rule from within the logical space of rule itself. 
Freedom as no-rule has no need for the limits of justice because it does not recognize the necessity of rule to begin with: hence it cannot pose itself the problem of limiting rule. Political freedom as no-rule does not dominate, and consequently it does not need to be limited by considerations of justice. 
Liberal and republican outcomes of the conflict between morality and politics

Morality finds itself relativized or situated in a situation characterized by the discord between rule and no-rule, domination and freedom. From this political situation, two opposed and irreducible determinations of modern political life follow. The first can be described as the liberal interpretation of the modern political situation. Whenever political freedom as no-rule is employed as the basis for political rule, then the discourse of justice tends to totalize the discourse of freedom, the claims of freedom are resolved into claims of justice, in short, the conflict between politics and morality is pacified. The pacification of the conflict between political freedom and morality always takes the form of an attempt to retranscendentalize, and de-situate, the moral point of view. This is done by arguing that the political situation is not a factical situation but, instead, a situation which falls under certain apriori (necessary and universal) norms, a situation which is "outside" of history and change and which is identical to a "state of nature," in the sense in which all modern natural right, from Hobbes to Rawls, understands this term.

The liberal interpretation always orients political life towards the goal of securing rule. The expression "to secure rule" has two equiprimordial senses. According to the first, it is a question of securing the agency of domination from 
contestation by the desire for no-rule (i.e., securing the state from revolution, rebellion, and so on). The second sense consists in making the practice of rule secure for those who are subjected to it by instituting constitutionally protected individual and political rights. As I show in my interpretation, the logic of securing the state from popular contestation by securing, in return, the people from the state is already prefigured in Machiavelli's discourse, even though this discourse does not use the language of right. After Machiavelli, the principle of securing rule is given the form of right: this is the modern political instrument invented by Hobbes to pacify the conflict between political freedom and morality.

Judged from the perspective of the originary political situation, one can say that the form of right serves to repress the irreconcilable discord between rule and no-rule. It has this power, first, because a right has an internal relation to coercion and thus to domination and rule. As Kant says: "there is connected with Right by the principle of contradiction an authorization to coerce someone who infringes upon it." 42 Political freedom as right requires this internal relation to coercion because it expresses a claim to justice, namely, the claim to the equal protection for all free agents. In this context, equality is a moral category because it presupposes that the problem is how to rule equally free agents. Once the question of ruling the equal freedom of everyone is posed, then the moral discourse enters with its answer: the ruling of equally free human beings can best be achieved if it is fair, hence through 
the equal protection of all the interested parties. Only at this point is the discursive space for a theory of justice ready to be occupied.

A decisive difference must be drawn between the factical condition that everyone is equally free, which is extra-moral, and the problem of how to rule the equal freedom of all, which is a moral problem and calls for a moral concept of equality. Equality is a political category when one is speaking about the "equality of all to make the law." As indicated above, Kant shows an awareness of this point when in the "First Definitive Article," of Perpetual Peace he defines political freedom as "a warrant to obey no external laws except those to which I have been able to give my own consent," that is, only those laws which I have given to myself. ${ }^{43}$ Kant's idea of freedom is linked to the idea of no-rule since it amounts to non-obedience to any source of external rule, and obedience only to an internal source of freedom (autonomy). Political equality springs from such an idea of freedom as no-rule: since freedom as no-rule cannot coerce anyone, everyone is free to be "free," i.e., to give oneself the law, and in this sense alone everyone is equal. This concept of political equality necessarily falls outside the sphere of the state, of its constitution, laws and orders since whoever is free to make or give the law cannot in turn determine this freedom by subsuming it under a previously existing law without denying it as such. Freedom as no-rule, indeed, entails a relation to such a political equality since this freedom is capable of contrasting the practice of rule 
only if it has access to the activity of law-making in the absence of the division between who commands and who obeys, i.e., in the absence of domination. This absence must be experienced by the political actors, and cannot be verified by the external law, since this law is itself a cause of domination. In contrast, when one speaks about the "equality of all under the law" one is referring to moral equality: the latter is a crucial principle for the limitation, and thus legitimation, of rule but not for the formulation of freedom as no-rule.

The second sense in which rights pacify the conflict between politics and morality is expressed by the fact that a right is a liberty which is always already negative. Negative liberty is freedom that has an internal relation to an external limit. For example, in the Leviathan Hobbes defines negative liberty in an internal relation to externally imposed laws: negative liberty is found wherever the laws are silent (silentio legis). Kant's sense of negative liberty is more vociferous in that he defines it as the liberty to think freely but not to act freely, i.e. to disobey: "Argue as much as you like and about whatever you like, but obey!"44 These senses of negative liberty are very different from the sense of freedom as no-rule which is a positive or factical freedom to negate any and every source of domination, i.e., which has an internal relation to the transgression of external limits or constraints. ${ }^{45}$ Needless to say, these external limits can also be the laws of the state. Therefore, the form of right is always already a negation of the negativity of freedom as no- 
rule: it works simultaneously for the sake of rule and for the sake of morality, i.e., it provides the ground for legitimate domination in modernity. The system of rights always organizes political action for the sake of the state: it carries forth the modern attempt to construct ethical substance, to seek the pacification and unification of the discord between politics and morality. The difference between ancient and modern ethical substances is that the modern pacification operates in a changed politicophilosophical situation where freedom, and not justice, is privileged. The system of rights is the only way in which it is possible to realize or give substance to freedom as no-rule. But the project to realize freedom as no-rule always runs the risk of dissolving this freedom: it gives this freedom the force to rule and thereby depotentiates its capacity to contest rule. It gives freedom its substantial reality and thereby cuts it off from its historicity, cuts it off from its situation as a situation to be changed, denying its transgressive potential. This is the aporia implicit in liberalism.

Conversely, whenever the political situation reproposes the irreconcilable conflict between politics and morality, freedom and justice, there obtains the second determination of modern political life: action becomes political only if it is oriented towards the goal of living free from rule. In these cases, the political situation becomes that situation in which the actor seeks a change of situation. Every pertinent instance of legitimate domination is suspended and contested in order to get the state to respond to the new claims for freedom from rule. All new instances 
of order have to originate from an interruption of a prior order, that is, have to find their beginning not from the domain of legal domination but from that of freedom as no-rule, from the suspension of the command-obey relation. Following Arendt, who defines the republic as a form of political life "where the rule of law, resting on the power of the people, would put an end to the rule of man over man," ${ }^{, 46}$ I call this determination the republican interpretation of the modern political situation.

The crucial aspect of the political situation once it enters its republican, as opposed to liberal, determination consists in its radical finitude: the situated change of situation is by definition a transgression that has the status of an event. In virtue of its transgressive potential, the republican moment contrasts every liberal attempt to put order in the political situation, to pacify the discord between rule and no-rule, to give substance to freedom. One can therefore speak of republican events in which political orders undergo revolutionary changes. But, at the same time, the moment of transgression is only an event: every attempt to give it a process-like or substance-like duration, every attempt to naturalize this intrinsically historical moment, denies the political situatedness of freedom itself because it does away with the discord between rule and no-rule for the sake of no-rule. In this reading of Machiavelli's formula, at the core of what Strauss calls the historicist dimension of modern political life, one finds the opposite of what Strauss charges: not the reduction of political action to technique, not the "mastery of chance" that 
determines historical becoming as the vehicle for the rationalization of the real, but the logical impossibility for instrumental rationality to predict, program or plan these events of transgression which escape the reach of all technique in virtue of their radical contingency and groundlessness. Likewise, no philosophy of history can be built on the basis of these events of freedom because what is transgressed and transcended in them is precisely the rational and moral construction of reality, the very unity of ideal and real, that is aimed at by the project of realizing the moral point of view in modernity, a project that is always (explicitly or implicitly) articulated through a philosophy of history.

The attempt to absolutize political freedom as no-rule, the attempt to pursue the chimera of a state of no-rule, an order of anarchy, can only lead to pure and limitless violence (as opposed to the legitimate violence employed by the state as system of rights). This is the phenomenon that Hegel called the Terror of absolute freedom. It constitutes the danger implicit in the modern republican determination of political life. Modern political freedom must be self-contesting because it is completely engaged by its political situation. This situation is a situation of conflicting interpretations of freedom, in which political freedom is torn into its liberal and republican moments, that alone can finitize political freedom in virtue of their irreducible discord. Modern political life preserves its freedom only if it can endure the oscillation between republican events of freedom as no-rule and liberal 
processes of expanding the system of rights, each moment avoiding the temptation to abolish its other.

In sum, the Machiavellian legacy to modernity consists in the plurivocal interpretations that are given to the originary political situation of the dissolution of ethical substance. In the liberal interpretation this dissolution is both accepted and sublated into a new ethical substance that takes the form of a system of rights. In the republican interpretation this dissolution is pursued into what Strauss would call its historicist, nihilist, and relativist consequences. But without this pursual the expansion of modern political freedom in both its republican and liberal interpretations would be impossible, because, as I indicated above in the case of Kant himself, the Kantian legacy of a moral understanding of freedom requires as its condition of possibility the Machiavellian legacy of a factical understanding of freedom, and not vice versa. The very opposition of these legacies, the fact that the Machiavellian legacy is also the condition of the impossibility of the realization of the Kantian idea of freedom, is precisely what allows both to survive. $^{47}$ 
Historicism and the modern ethos of freedom

Habermas confirms that the krisis in the classical unity of morality and politics does not have a unitary outcome but, in his words, gives rise to "the modern ideas of self-realization and self-determination" that are to be considered "not only different issues but two different kinds of discourse tailored to the logics of ethical and moral questions." ${ }^{48}$ One can assume, relatively unproblematically, that the Kantian legacy, from Hegel to Habermas, works out the logic of freedom as "selfdetermination" or moral autonomy. It would not be stretching matters too far to claim that the logic of freedom corresponding to "self-realization" or political virtù, initiated by Machiavelli's discourse, finds its continuation in the late modern discourses of Nietzsche, Weber and Foucault. These discourses are identified, by Strauss as much as by Habermas, with the completion of modern self-assertion in the discursive traits of historicism, nihilism and relativism. It is now possible to indicate how these traits emerge as a function of an ethics of responsibility that responds to the modern situatedness of morality brought about by the centrality of factical freedom.

Foucault's interpretation of the Kantian Enlightenment serves this purpose for three reasons. ${ }^{49}$ First, this nontraditional reading frames Kant's discourse in a continuity of sorts with those of Machiavelli and Nietzsche. In so doing, it coincides 
with Strauss's description of the "three waves"of modernity. For that reason Foucault is able to offer a direct response to the Straussian claim that modernity is thoroughly historicist and leads to moral relativism by redescribing historicism as the essential feature of the modern ethos of freedom. This move radicalizes the internal relation between freedom and history that constitutes the fundamental innovation of Machiavelli's discourse according to the interpretation I have given of it.

Second, Foucault's reading of the Enlightenment revives the conflict between the two logics of modern political freedom that is tendentially compromised, if not extinguished, by the strategy of universalism espoused by the Kantian legacy. Since the concept of freedom as moral autonomy presupposes the commensurability of freedom and law, its discursive articulation cannot but advance the claims of universalism that are inherent in every justification of the law that appeals to its formal characteristics. As a consequence, the Kantian legacy not only finds it extremely difficult to articulate a critique of its own universalism, but it also exhibits a strong tendency to reduce the logic of "self-realization" as political virtù to the claims of particularism, with the result that the standpoint of an ethics of responsibility is radically depoliticized. ${ }^{50}$

Such a reduction of the Machiavellian legacy to a form of political particularism is unwarranted. The discourse of self-determination or moral freedom, 
in virtue of the internal link between noumenal freedom and the form of the law, conceives of the self as free only on condition that its praxis is (or tends towards the) necessary and universal. It operates under the basic assumption that only in this situation of necessity and universality is it apriori possible for praxis not to encounter any resistance and as a consequence to be truly free praxis. Conversely, Foucault's presentation of the practice of self-realization or political virtù reiterates the internal link between factical freedom and the transgression of the law. As a consequence, it conceives of the self as free in so far as it divests itself of those identity-formations (both universal and particular ones) that give a necessary form to its praxis, in order to win for this praxis a space of freedom from necessity. If it is certainly the case that this latter conception of freedom cannot be "necessary and universal," it would be a philosophical error to assert that it must therefore be "contingent and particular." Freedom as political virtù lies outside of the dualism universal/particular, as much as that of necessary/contingent, because its facticity refers to the event-character of the difference between contingency and necessity (i.e., to the finite transcendence of this difference such that one can be convertible into the other), and this feature allows the discourse of factical freedom to maintain the historicity of every determination of universality (and thereby of particularity, which is logically dependent on the former). 
Third, by focusing on the link between the question of the Enlightenment and that of revolution in the Kantian corpus, Foucault's reading recovers at the center of Kant's noumenal conception of freedom the anterior trace of the Machiavellian, factical conception of freedom. In this way, Foucault indicates how the discourse on modernity carried forward by the project of Enlightenment, which turns on the possibility of the moral progress of humanity, cannot be separated from the idea of modernity as a situation in which revolutionary changes of situation become possible. From the point of view developed in this book, Foucault's discourse recapitulates, in an extremely concentrated form, the central motifs exhibited so far in the presentation of the origin and outcomes of the conflict between politics and morality in modernity.

If for Strauss historicism means that philosophy or theory no longer has access to supra-historical or ahistorical validity-grounds, then Foucault's idea of the Enlightenment is thoroughly historicist. According to him, Kant's question of Enlightenment serves to recast philosophy, in the situation of modernity, as a practice that is relative to its historical situation: "philosophy as problematization of an actuality, and as questioning of this actuality on the part of the philosopher who belongs to this actuality and in relation to which he must be situated, all this could characterize philosophy as a discourse of modernity and on modernity." ${ }^{51}$ An essential trait of the situation of modernity is the impossibility of gaining a 
philosophical or theoretical understanding of this situation that, simultaneously, lies outside of it. The philosophical understanding of the situation of modernity must itself be situated in modernity, and that is why there cannot be one such understanding. ${ }^{52}$ Nothing less follows from the priority of event over form in modernity and the two ineluctible yet conflictual understandings of modern political freedom that articulate this priority.

The historicism that Foucault individuates in the project of the Enlightenment is not as such a theoretical position designed to refute the primacy of theory over practice characteristic of classical political philosophy. If it were, it could not survive the objection of pragmatic contradiction levelled to all merely theoretical articulations of relativistic claims. On the contrary, for Foucault the question of Enlightenment is a practical matter of reflecting "on 'today' as difference in history and as motive for a particular philosophical task," ${ }^{, 53}$ i.e., it is a question of illuminating the present as a situation in which a change of situation can be practically effected. In so far as historicism is an essential moment of this illumination, then it is an essential element of the ethos or practice of modern factical freedom. To be modern, to exhibit what Foucault calls the "attitude of modernity, ${ }^{, 54}$ in this sense, means to experience as praxis the radical historicity of one's situation. To put it in the language of Machiavelli, to be modern means to encounter one's situation with virtù, that is, in view of effecting its change. 
This historicism of modernity also avoids the charge of self-refutation in a different way, which is connected to the "realism" that Strauss imputes to it. Unlike the naïve idea of historicism held by Strauss, the historicism illustrated by Foucault does not consist in subjecting the purportedly atemporal determinations of validity to the empty continuum of linear time, for if this were the case, then the claims of historicism as well would have to be subject to the linear passage of time, and in that way itself pass away. ${ }^{55}$ What makes historicism into an ethos, rather than a theory, is precisely that it does not accept the linear passage of time as an unsurpassable fact. Rather than succumbing to the "vertigo in the face of the passing moment," ${ }^{, 56}$ it assumes a "certain attitude with respect to this movement... [which] consists in recapturing something eternal that is not beyond the present instant, nor behind it, but within it." ${ }^{, 57}$ Historicism as ethos, in other words, finds through time a way out of time, or, better, finds a way to suspend and reverse the empty and linear passage of time, acceding to what Foucault here refers to "eternity."

Historicism as ethos accomplishes this break with linear temporality because it "is the will to heroize the present." ${ }^{, 58}$ The realism that Strauss imputes to modern historicism acquires a new sense in Foucault's definition of modern heroism as "an exercise in which extreme attention to what is real is confronted with the practice of a liberty that simultaneously respects this reality and violates it." ${ }^{, 59}$ In the situation of modernity, what passes for objective reality is something whose 
"eternal" aspect is "indissociable from a desperate eagerness to imagine it, to imagine it otherwise than it is, and to transform it not by destroying it but by grasping it in what it is." ${ }^{60}$ The paradox of this formulation is only apparent: historicism seeks to determine the reality of the situation, but precisely the more the situation reveals itself as such, in its reality, "in what it is," the more it becomes something that can be imagined otherwise, transformed, virtualized because it belongs to the essence of a situation that it can be changed. And the change, transgression or transcendence of the situation, in that it requires the revolutionizing of the times, the suspension of their linear progress, the destruction of their tradition, is what accounts for the dimension of "eternity" that exists "within" the "present instant" of the situation in question.

Historicism as ethos, as "the practice of a liberty that simultaneously respects reality and violates it," exhibits a pathos against necessity that accounts for its conflict with the moral conception of freedom in the Kantian legacy.

If the Kantian question was that of knowing what limits knowledge has to renounce transgressing, it seems to me that the critical question today has to be turned back into a positive one: in what is given to us as universal, necessary, obligatory, what place is occupied by whatever is singular, contingent, and the product of arbitrary constraints? The point, in brief, is to transform the critique conducted in the form of necessary limitation into a practical critique that takes the form of a possible transgression. ${ }^{61}$

By advocating the relative priority of politics over philosophy, praxis over theory, Foucault retrieves the Machiavellian rupture with the ancients in order to contest the "theoretical" bias, the "antiquity" that is still present in the Kantian articulation of 
modern critique. The priority of politics over philosophy is advanced as a function of an ethics of transgression whose criterion for free action is the transformation of the necessary into the contingent, and vice versa. If for philosophy "necessity" is the terminus ad quo, then for modern politics it is the terminus ad quem, namely, it is that limit which can be transcended or transgressed.

Foucault's reversal of the course taken by critique in the Kantian legacy is simply the adoption and radicalization of the priority of the event over the form that characterizes Machiavelli's discourse:

Criticism is no longer going to be practiced in the search for formal structures with universal value, but rather as a historical investigation into the events that have led us to constitute ourselves and to recognize ourselves as subjects of what we are doing, thinking, saying. In that sense, this criticism is not transcendental... it is genealogical in its design and archeological in its method. ${ }^{62}$

Moving away from the priority assigned to form, critique passes from the identification of necessary limits as transcendental structures (i.e., of necessary and universal conditions of possibility of objects of experience), to the retrieval of the contingent origins of what is taken to be necessary in any given time.

A critique that assumes the priority of event over form is a genealogical, as opposed to transcendental, critique:

[the genealogical critique/MV] will not deduce from the form of what we are what it is impossible for us to do and to know; but it will separate out, from the contingency that has made us what we are, the possibility of no longer being, doing, thinking what we are, do, or think. It is not seeking to make possible a metaphysics that has finally become a science; it is seeking to give new impetus, as far and wide as possible, to the undefined work of freedom. ${ }^{63}$ 
The genealogical articulation of critique understands the difference between the necessary and the contingent to be rooted in events, thus as itself contingent and changeable. To show how the necessary can become contingent and the contingent can become necessary are the respective tasks of genealogy and archeology. ${ }^{64}$ In line with the basic assumption that the Machiavellian legacy does not exclude the Kantian one but both enables and limits it, Foucault thinks of archeology as a practice that substitutes for, rather than eliminates, the search after transcendentals in the Kantian legacy: archeology uncovers the different "historical aprioris" of discourse, with an emphasis on the process whereby a contingent event, a given expression, attains its apriori status. ${ }^{65}$ Genealogy, conversely, is that aspect of critique that negates the apriori as such by bringing back the form to the point of its event-like emergence, and opens the possibility of transgressing its limit.

The ethos of freedom, then, consists in "a historico-practical test of the limits that we may go beyond, and thus as work carried out by ourselves upon ourselves as free beings." 66 But what kind of "work" qualifies the self as a modern "hero," capable of carrying out "this ironic heroization of the present, this transfiguring play with reality" ${ }^{67}$ The work performed by the self on itself moves in the opposite direction of autonomous self-determination that is achieved by giving itself universal and necessary laws. Instead of identifying freedom with reason's 
counterfactual capacity to transcend every situation as such, the "hero" of modernity is "the man who tries to invent himself," who faces "the task of producing himself,"68 in order to exercise the capacity to remove "conditions of necessity," i.e., to garner the power to change the situation in which any given norm or law appears endowed with necessity and universality. This "heroism" is ironical because it orients the self toward the de-realization of "what is not or is no longer indispensable for the constitution of ourselves as autonomous subjects." ${ }^{69}$ Indeed, modern self-assertion, as Foucault conceives of it, is best expressed as the practice of self-virtualization rather than self-realization because it entails an experience of the alterity of the constructs of self-identity. To be factically free means to be capable of being otherwise.

According to the Kantian legacy, the moral presupposition of the horizon of a common humanity (Kant's idea of Menschheit) allows the self to recognize the other as another self. The other, in this model, is the nothingness of the self which it needs to overcome in order to attain the identity of humanity, the mutual recognition of self and other that Fichte expresses in the formula "I=I" and that Hegel defines as "spirit" [Geist]. For the Kantian legacy, then, one may speak of the "nothingness," of the lack of essence, of humanity as a function of seeing the other as another self. $^{70}$ 
Foucault contests the appeal to the value of "humanity," or universal selfidentity, as something already given, if only as a regulative ideal for all the transformations of the self, i.e., for all permutations of becoming-otherwise, on the grounds that it goes against

the principle of a critique and a permanent creation of ourselves in our autonomy: that is, a principle that is at the heart of the historical consciousness that the Enlightenment has of itself. From this standpoint, I am inclined to see Enlightenment and humanism in a state of tension rather than identity. ${ }^{71}$

Critique stands in tension with humanism to the extent that it valorizes the capacity of the self to become other to itself, to transcend and transgress its constructs of self, as a function of its openness to an other who challenges the predetermined horizon of what counts as humanity, no matter how wide or abstract this horizon is factually drawn. If the humanist ideal always seeks the egoicity of the other, the Machiavellian legacy carried forward by Foucault stands for the experience of the alterity of the self in virtue of which each (human) being has access to its singularity, to the aspect of humanity that comprehends each (human) being in so far as it is an exception to the universal, in so far as it stands outside of the law. To become singular in this way means to open the self to the irreducible plurality of (human) beings and their factical freedom, a plurality that pragmatically calls into question the existence of Man. 
The necessary complementarity, achieved only through conflictuality, of the Machiavellian and Kantian legacies re-emerges on this issue of nihilism. For the latter, the value of humanity underpins all of the fundamental rights. For the former, this value (as the highest value) must be put into question as part and parcel of the republican interpretation of the modern political situation that carries with it a critique of the system of rights in the name of freedom as isonomy or no-rule. Modern isonomy not only entails equality under the rule of law but also equal capacity to make and unmake the law in conditions of no-rule. ${ }^{72}$ The latter equality cannot itself fall under the form of law, therefore it factically opens the system of rights beyond those who are already "equal under the law" (even the moral law) to those who are systematically unequalized or excluded by virtue of the law (even the moral law).

It is possible to give a sketchy topography of who remains "outside" of the system of rights, of the "outsiders" that the republican understanding of isonomic freedom seeks to address. They are the ones who remain caught in the exclusionary circle that characterizes the liberal understanding of the tension between natural or human rights and political rights, the vicious circle whereby to have one's human or natural rights recognized it is already necessary to be a citizen and have political rights, while the constitution and attribution of these political rights ought to presuppose the prior recognition of natural or human rights. ${ }^{73}$ Here I must limit 
myself to indicate that the exclusionary dynamic of the modern system of rights is explained by the fact that the form of political intersubjectivity to which the self must belong in order to be recognized as "human," and therefore as endowed with natural or human rights, is always already culturally predetermined, whether in a particularistic or universalistic sense. ${ }^{74}$ In other words, the presupposition of natural or human rights is understood as cultural fact: in its particularistic variant, the cultural fact usually refers to purportedly irrevocable attachments to given political or religious forms; in its universalistic variant, the cultural fact refers to purportedly irrevocable attachments to context-independent rational or argumentative forms. In neither case is the cultural fact inherently open to interpretation and contestation.

It is on the seemingly irrevocable character of such cultural facts that factical freedom as the practice of self-virtualization sets itself to work in order to performatively dissolve the cultural fact into what might be called a cultural right, understood as a free space for political self-invention in the sense given to this term by Foucault's concept of an ethos of freedom. One can say that the nihilistic pursuit of factical freedom described by Foucault, a pursuit that orients itself not to the humanity which it has already become but to the humanity which it has not yet transgressed itself into, coincides with the pursual of what Arendt calls the "right to have rights."75 
If what I call a cultural right and Arendt calls a "right to have rights" denotes the right to "a place in the world which makes opinions significant and actions effective," ${ }^{, 76}$ then under the liberal interpretation of the modern political situation this right is not recognized as such, as a space of freedom, but is rather assumed as a fact that conditions the entrance into the modern system of rights, and narrows the possibilities of modern freedom. Conversely, the "place in the world" where what one says passes from being insignificant, either because unheard or already said, to being significant, and what one does passes from being ineffective, either because ignored or already done, to being effective does not designate a physical or geographical place at all, but rather marks out the limits and function of the modern political situation under its republican interpretation. The exercise of the "right to have rights" coincides with the exercise of factical freedom as self-virtualization; its "place" corresponds to the republican event of freedom; its ethics are those of responsibility. For the appeal to a discourse of responsibility is needed only once freedom and law (whether heteronomously or autonomously given) are no longer commensurable, that is, only in those events of political changes of laws and orders that originate in the expression of freedom as no-rule. Only when freedom cannot be ruled by law, or when freedom exceeds the rule of law (in both of its facets: that of legality as much as that of legitimacy) is there space for an ethics of responsibility that stands outside of the discourse of morality. For it is clear that where the law 
rules over human praxis it is impossible to accede to a position of intrinsic responsibility for this praxis: this position is only available in the case of a transgression of the law that is not in turn commanded by a higher law. ${ }^{77}$

The formulation of the question of Enlightenment in terms of the right to have rights is inseparable from the republican interpretation of the modern political situation as a revolutionary event, as a situation in which radical changes of situation can happen. One may therefore read Foucault's linkage of the question of Enlightenment to the question of revolution in the Kantian corpus as an effort to think together the republican and the liberal interpretations of the modern political situation, to articulate the right to have rights as revolutionary event, on the one side, and the system of rights as ground of political form, on the other. ${ }^{78}$

In The Conflict of the Faculties, Kant addresses the phenomenon of modern revolution in the process of settling the conflict between the Enlightenment project of philosophy (the faculty of philosophy) and the discourse of legitimacy (the faculty of law). The solution Kant offers passes turns on his "renewed attempt to answer the question: 'is the human race continually progressing?'."79 Foucault reads Kant's solution as follows:

if one wants to answer the question "is there a perpetual progress of humankind?" one must determine whether there exists a possible cause of such progress, but once one has established this possibility, one has to show that this cause effectively acts, and for that one needs to identify a certain event that shows that the cause acts in reality. In short, the assignment of a cause will never be able to determine anything except possible effects, or 
more exactly the possibility of an effect, but the reality of an effect can only be established by the existence of an event. ${ }^{80}$

Kant famously identifies such an event in the French Revolution. Granted that the very idea of Enlightenment stands or falls on the possibility of the "perpetual progress of humankind," the question of revolution cannot be separated from this progress itself, nor from the regulative ideal of morality that rules over this progress, because both depend on the existence of an event of freedom that is both revolutionary and factical in character. Therefore at the heart of Kant's noumenal conception of freedom Foucault locates the anterior trace of a factical conception of freedom, i.e., of a conception of freedom that is internally linked to its event understood as the revolutionary change of situation. ${ }^{81}$

In this sense, Foucault is interested in showing how the liberal system of rights that Kant derives from the application of noumenal freedom ${ }^{82}$ reveals itself as conditioned by republican events of freedom that both permit and limit the possibility of raising questions of normative validity in a strictly universal sense. ${ }^{83}$ The argument that subtends Foucault's interpretation of Kant is as follows: the transcendence of the norm over the situation, such that it is capable of applying to that situation and thus showing itself to be valid, is not something given by the form of the law itself. Rather, what gives a norm the possibility of being valid, i.e., of applying to a given situation in virtue of its transcendence of the situation, is the 
prior condition that this situation be, always already, capable of being changed. Since the change of situation, by definition, cannot be overseen by the norm as such, this change can be nothing other than the effect or event of factical freedom that I am calling here a "revolution" and that corresponds to the republican event of freedom.

When the revolution is understood as an event of factical freedom it functions both as the condition of possibility and impossibility of the Enlightenment concept of history as progressive realization or constitution of moral freedom. As Foucault argues,

The revolution, in any case, will always risk falling to the wayside, but as an event whose content itself is unimportant, its existence attests to a permanent virtuality that cannot be forgotten: for future history, it is itself the guarantee for the continuity of the movement towards progress [d'une démarche vers le progrès]. ${ }^{84}$

The event of freedom expressed in the revolution does not derive its peculiar significance from its specific political content, but from the facticity of its happening: there is a "future" for history, and therefore for "perpetual progress," only on condition that events of freedom happen again, i.e., only on condition that the empty continuum of time is repeatedly broken down, interrupted, reversed, revolutionized. Revolution is "a permanent virtuality that cannot be forgotten": it does not mark the realization of an idea of freedom, as much as the virtù-alization of 
the "objective reality" of law and order along with the "ideal" validity that maintains them in existence.

Foucault's characterization of the revolutionary event is only understandable against the background offered by the theory of political action found in Machiavelli's discourse. An action is factically free in virtue of its capacity to change the times: this change is defined by the polemical encounter (riscontro) between action and the times. Because the collision of action and time fragments (literally: concusses) the result of the action, one can say that what is done is always already incomplete and unfulfilled. This trait of political action accounts for the belief that events are never "complete" or "whole" as such, and, as a consequence, their judgment cannot be a matter for ex post facto reflection. Historical judgment, the judgment on history, is therefore a practical matter, a question of the ethos of freedom. Furthermore, it is the same conflictual character of the encounter between action and times that results in the un-hinging of the times, in their being set "out of joint," thereby calling into question both the linearity and irreversibility of the passage of time, which is the presupposition behind every conception of the "irrevocable" character of action ("what is done cannot be undone"). These two traits of free praxis characteristic of the Machiavellian legacy serve to account for the sense in which the revolution is, in Foucault's striking formulation, a "virtuality that cannot be forgotten." 
Indeed, understood as the expression of factical freedom, the significance of revolution according to the Machiavellian legacy does not consist in the political forms and orders that it might construct but, on the contrary, in its power to testify that what is done is also, always already, undone: the revolution is a "virtuality" in the sense that its force consists in virtualizing reality. Similarly, a revolution "cannot be forgotten" in the sense that in the actuality of the present as revolutionary situation, the "past," what was done, is never past. The "past" is never really past because what is done is always radically incomplete, unfinished, concussed, and for that reason it withholds the possibility of its own un-doing, the possibility of withdrawing the irrevocability of what exists. Just like the past is never a completed state of affairs, so too the state (or political form) can never hope to totalize itself in history: in the republican events of freedom that suspend the validity of political forms and reduce them to their an-archic origins, the past finds its future, the one that can "accomplish" or "judge" it, and in so doing bring the linear passage of time to a halt in what Machiavelli calls the (eternal) return of beginnings and Benjamin refers to as the apokatastasis (restitution) of history. ${ }^{85}$

If the action that changes the times is always an un-doing of what was done, then one cannot be "done with it": revolutions either (eternally) return or they do not exist. For this reason Foucault remarks that their existence is that of a memory ("they cannot be forgotten"), since memory is essentially what returns, it is 
repetition as praxis. Just as Machiavelli believes that only morally-contradictory actions of "extraordinary virtù," i.e., actions that "return to beginnings" and effect republican events, testify to the fact that "in republics there is a greater life, a greater hatred, more desire for revenge that neither lets, nor can let the memory of ancient freedom rest, ${ }^{, 86}$ so for Foucault the revolution is precisely that event whose "memory" exists as a genealogical counter-memory, that is, whose event gives rise to that peculiar memory that carries the contra-diction of the an-archic trait of the situation of modernity "against the grain" of history and its "perpetual progress," that resists and counters the "official memory" of the victors, established in the institutions that last, in the works of "civilization" that only the vision of Benjamin's angel of history can show to be a series of ruins, the fragments of history's res gestae. $^{87}$

The Machiavellian legacy to modern politics has always been accused of harboring a demonic vision of politics as the activity of founding political forms of domination. One should not forget that, to the extent that it does so, it is never without the corresponding angelic vision of history that leaves open the "narrow door" of the republican event of freedom. That the Machiavellian legacy of political freedom consciously deprives itself of the Kantian formulation of the categorical imperative does not mean that it has none. "Act in such a way that the angels have 
something to do, ${ }^{, 88}$ is perhaps the one imperative that an ethics of responsibility as ethics of freedom can stand for. 
${ }^{1}$ Leo Strauss, "The Three Waves of Modernity," in An Introduction to Political Philosophy (Detroit: Wayne State University Press, 1989), 91.

${ }^{2}$ Ibid., 82.

${ }^{3}$ Leo Strauss, On Tyranny (New York: Free Press, 1991), 106. Emphasis mine.

4 "Was vernünftig ist, das ist wirklich; und was wirklich ist, das ist vernünftig." (Hegel, Philosophy of Right, Preface).

${ }^{5}$ Strauss, "Three Waves of Modernity," 87.

${ }^{6}$ Ibid.

${ }^{7}$ Ibid., 86

${ }^{8}$ Ibid.

${ }^{9}$ Hans Blumenberg, The Legitimacy of the Modern Age (Cambridge: MIT Press, 1983), 138. ${ }^{10}$ Ibid., 141.

${ }^{11}$ As Strauss argues: "Machiavelli rejects the whole philosophic and theological tradition.... One must start from how men do live; one must lower one's sights. The immediate corollary is the reinterpretation of virtue: virtue must not be understood as that for the sake of which the commonwealth exists, but virtue exists exclusively for the sake of the commonwealth; political life proper is not subject to morality; morality is not possible outside of political society; it presupposes political society; political society cannot be established and preserved by staying within the limits of morality, for the simple reason that the effect or the conditioned cannot precede the cause or condition. Furthermore, the establishment of political society and even of the most desirable political society does not depend on chance, for chance can be conquered or corrupt matter can be transformed into incorrupt matter." (Strauss, "Three Waves of Modernity," 86-87).

${ }^{12}$ Luc Ferry, Political philosophy 1. Rights: the new quarrel between the Ancients and the Moderns. (Chicago: University of Chicago Press, 1990).

${ }^{13}$ Ferry, Political Philosophy 1, 122.

${ }^{14}$ See the argument in Luc Ferry, Political Philosophy 2. The System of Philosophies of History (Chicago: University of Chicago Press, 1992).

${ }^{15}$ Jürgen Habermas, "The classical doctrine of politics in relation to social philosophy," in Theory and Practice (Boston: Beacon Press, 1973), 54. See also his claim that "if the theoretically based point of departure of the Ancients was how human beings could comply practically with the natural order, then the practically assigned point of departure of the Moderns is how human beings could technically master the threatening evils of nature." (Ibid., 51).

${ }^{16}$ Habermas illustrates the internal relation and "radical tension between facticity and validity," as follows: "validity claims are Janus-faced: as claims, they overshoot every context; at the same time, they must be both raised and accepted here and now if they are to support an agreement effective for coordination - for this there is no acontextual standpoint. The universalistic meaning of the claimed validity exceeds all contexts, but only the local, binding act of acceptance enables the validity claims to bear the burden of social integration for a context-bound everyday practice." (Jürgen Habermas, Between facts and norms [Cambridge: MIT Press, 1996], 21). 
${ }^{17}$ My usage of the term "facticity" is close to Heidegger's employment of the term Faktizität in his writings around Being and Time. See, for example, Martin Heidegger, Ontologie:

Hermeneutik der Faktizität (Frankfurt: V. Klostermann, 1995).

18 "Chance is not simply the drawing of lots, but raising the stakes in every attempt to master chance through the will to power, and giving rise to the risk of an even greater chance. The world we know is not this ultimately simple configuration where events are reduced to accentuate their essential traits, their final meaning, or their initial and final value. On the contrary, it is a profusion of entangled events." (Michel Foucault, "Nietzsche, Genealogy, History," The Foucault Reader [New York: Penguin, 1991], 89).

${ }^{19}$ Habermas, Between facts and norms, 17.

${ }^{20}$ Roughly speaking, these three possibilities are represented in the three versions of Kantian constructivism found, respectively, in the thought of Habermas, Rawls, and Ferry.

${ }^{21}$ Strauss, "Three Waves of Modernity," 88.

${ }^{22}$ Similarly, Stuart Hampshire argues in Innocence and Experience (Cambridge: Harvard University Press, 1989) that Machiavelli's discourse, more so than Nietzsche's, poses the most intractable problems for a moral view of politics.

${ }^{23}$ Machiavelli, Prince, XV.

${ }^{24}$ One can say that Machiavelli is simply drawing the consequences of Plato's belief that "those who practice philosophy in the right way [i.e., in order to live the good life/MV] are in training for dying." (Plato Phaedo 67e).

${ }^{25}$ Kant, Perpetual Peace, Third Definitive Article, First Supplement, in Political Writings, ed. Hans Reiss (New York: Cambridge University Press, 1991), 112-113.

${ }^{26}$ Jürgen Habermas, "Law and Morality," in The Tanner Lectures on Human Values VIII (New York: Cambridge University Press, 1988): 217-279.

27 "In the legal mode of validity, the facticity of the enforcement of law is intertwined with the legitimacy of a genesis of law that claims to be rational because it guarantees liberty." (Habermas, Between facts and norms, 28).

${ }^{28}$ As Foucault says, politics "is war, a war continued by other means." (Michel Foucault, "Two Lectures," in Power/Knowledge: selected interviews and other writings 1972-1977 [New York: Pantheon, 1980], 90).

${ }^{29}$ Strauss, "Three Waves of Modernity," 82.

${ }^{30}$ Machiavelli, The Prince, XXV.

${ }^{31}$ Strauss, "Three Waves of Modernity," 82.

32 "Not only being known is present in the things known as a consequence of the good, but also existence and being are in them besides as a result of it, although the good is not being but is still beyond being [epekeina tes ousias], exceeding it in age and power." (Plato Republic, 509b-c).

${ }^{33}$ Plato Laws 710a-d; Aristotle Nicomachean Ethics 1109a25-30.

${ }^{34}$ Strauss, "Three Waves of Modernity," 86. Strauss also says that for the ancients justice is "compliance with the natural order." (Ibid., 87).

35 Aristotle expresses the doctrine that "to rule and be ruled" (to command and to obey) is something good because it allows for the attainment of a virtuous character: "It has been well said that he who has never learned to obey cannot be a good commander. The excellence of the two is not the same, but the good citizen ought to be capable of both; he should know how to govern 
like a freeman and how to obey like a freeman - these are the excellences of a citizen. And, although the temperance and justice of a ruler are distinct from those of a subject, the excellence of a good man will include both." (Aristotle Politics 1277b12-20).

${ }^{36}$ Aristotle Politics $1280 \mathrm{~b} 5$.

${ }^{37}$ One can object that in Aristotle the good is situational, in the sense that for every situation, what is good changes. Indeed, Aristotle deflates Plato's chorismos between the idea of the good and the situation, and that is why it is difficult to draw a "principled" or metaphysically-derived distinction between ends and means in Aristotle's ethics. From here the famous problem of whether phronesis ranges over the means only or over both means and ends. Nonetheless, Aristotle maintains the transcendence of the good over the situation because there is an unbridgeable gap between the claim that for every situation the good changes and Machiavelli's idea that the good is itself situated.

${ }^{38}$ Aristotle employs the expression: "the goal of an action reflects the occasion [to de telos tes praxeus kata ton kairon estin]." (Aristotle Nicomachean Ethics 1110a14). Aubenque claims that already in Pindar (Nemean Odes III ,74-5) one finds the concept of a faculty or sense, termed phronein, that allows human beings to "do what is good in time, en kairou." (Pierre Aubenque, La prudence chez Aristote [Paris: PUF, 1963], 105).

${ }^{39}$ Machiavelli, Discourses on Livy, I,5.

${ }^{40}$ Kant, Perpetual Peace, First Definitive Article, in Political Writings, 99.

${ }^{41}$ Machiavelli, Prince, IX. Needless to say, the primacy of discord and conflict in modern political life has been admitted unanimously: from Hobbes's insistence that political unity must be thought starting from the possibility of a "war of all against all," to Kant's "social unsociability," Hegel's "master-slave dialectic," Marx's "class conflict," etc.

${ }^{42}$ Kant, Metaphysics of Morals, (New York: Cambridge University Press, 1991), 57. Kant derives this idea from Rousseau: there the system of rights finds its origin in the general will or sovereignty of the people. But in the sovereign, facticity and validity are united: "The sovereign by the mere fact that it is, is always all that it ought to be." Precisely because of this unity, the concept of right is apriori linked to the possibility of coercion: "in order that the social contract [instituting the sovereign/MV] shall not be an empty formula, it is tacitly implied in that commitment - which alone can give force to all the others - that whoever refuses to obey the general will shall be constrained to do so by the whole body, which means nothing other than that he shall be forced to be free." (Rousseau, Social Contract, I,7).

${ }^{43}$ Kant, Perpetual Peace, "First Definitive Article."

${ }^{44}$ Kant, An Answer to the Question: 'What is Enlightenment?' in Political Writings, 55. See also Kant's other formulation: "Thus freedom of the pen is the only safeguard of the rights of people, although it must not transcend the bounds of respect and devotion towards the existing constitution, which should itself create a liberal attitude of mind among the subjects." (Kant, On the Common Saying: 'This May be True in Theory, but it does not Apply in Practice,' "On the Relationship of Theory to Practice in Political Right," in Political Writings, 85).

${ }^{45}$ To give a famous example from the history of civil disobedience in the United States: Rosa Parks' decision "not" to move seats in a segregated bus cannot be described as an exercise of her negative liberty, but it is an expression of her factical and transgressive freedom as no-rule. 
${ }^{46}$ Hannah Arendt, "On Violence," in Crises of the Republic (New York: Harcourt Brace, 1972), 150.

${ }^{47}$ I borrow the idea of a "condition of possibility and impossibility" from Derrida, who speaks about structures that are originary without exhibiting "the simplicity of a logical or transcendental principle.... One must speak of... a double root [that] cannot play the role of philosophical radicality. All problems emerge from the fact that this non-simplicity at the same time permits and limits." (Jacques Derrida, Limited Inc [Paris: Galilée, 1990], 171).

${ }^{48}$ Habermas, Between facts and norms, 95.

${ }^{49}$ I refer to two versions of the text "What is Enlightenment?". The first, "Qu'est-ce que les Lumières?,” in Michel Foucault, Dits et Ecrits: 1954-1988 (Paris:Gallimard, 1994), 4: 679-688 was first published in Magazine littéraire 207 (1984), and is an extract of Foucault's course at the Collège de France, January 5, 1983. It precedes, therefore, the English version of "What is Enlightenment?" in The Foucault Reader prepared by Foucault in 1984.

${ }^{50}$ This move is evident in Habermas's description of "self-realization": "To put it briefly, in place of exemplary instructions in the virtuous life and recommended models of the good life, one finds an increasingly pronounced, abstract demand for a conscious, self-critical appropiation, the demand that one responsibly take possession of one's own individual, irreplaceable, and contingent life." (Habermas, Between facts and norms, 96). The reduction of the concept of freedom as virtù to the domain of particularism is not only applied to the self but also to the community. Hence the "self-realization" of a community, the search for the "common good," etc. are also seen as instances of particularism. (See the discussion of republicanism in Rawls, Political Liberalism.) The problem does not consist in the claim that discourses on the "good," whether communal or inidvidual, are particularist. Rather, the problem lies with the employment, in authors like Rawls or Habermas, of the term "ethical" exclusively to qualify such moral particularism, making it harder to employ the term for an extra-moral discourse on freedom, as I am advocating here.

${ }^{51}$ Foucault, Dits et écrits, 4: 681.

${ }^{52}$ In The Philosophical Discourse of Modernity that appeared two years later Habermas agrees in principle with Foucault's point regarding the historical situatedness of philosophy in modernity. The disagreement between them is whether this situatedness of philosophy should be understood in accord with the Hegelian strategy whereby philosophy, through a phenomenological reconstruction of modernity, has the "task of grasping its own time... in thought" (Jürgen Habermas, The Philosophical Discourse of Modernity [Cambridge: MIT Press, 1987], 16); or whether it is better understood in accord with the Nietzschean attempt to provide a genealogy of modernity, i.e., what Foucault calls "a critical thought that takes the form of an ontology of ourselves, of an ontology of the present [une ontologie de nous-memes, d'une ontologie de l'actualité]." (Foucault, Dits et écrits, 4: 687).

${ }^{53}$ Foucault, "What is Enlightenment?," 38.

54 Ibid., 38.

${ }^{55}$ This argument against historicism is found, among other places, in Leo Strauss, "Political Philosophy and History," in What is Political Philosophy? (Chicago: University of Chicago Press, 1988), 64. Karl-Otto Apel has formulated it more recently as follows: "die (transzendentale!) Abhängigkeit der Gültigkeit des Denkens und Erkennens von irgendeiner Form der Innerzeitigkeit 
- dies wird noch anhand des postheideggerschen Panhistorismus der gegenwart zu zeigen sein lässt sich nicht einmal selbst als gültig denken bzw. aussagen." (Karl-Otto Apel, "Sinnkonstitution und Geltungsrechtfertigung. Heidegger und das Problem der Transzendentalphilosophie," in Martin Heidegger: Innen- und Aussenansichten (Frankfurt: Suhrkamp, 1989), 150.

${ }^{56}$ Foucault, "What is Enlightenment?," 39.

${ }^{57}$ Ibid., 40.

${ }^{58}$ Ibid.

${ }^{59}$ Ibid. Emphasis mine.

${ }^{60}$ Ibid.

${ }^{61}$ Ibid., 45.

${ }^{62}$ Foucault, "What is Enlightenment?," 46. Emphasis mine.

${ }^{63}$ Ibid., 46.

${ }^{64}$ Foucault elsewhere presents the idea behind the coupling of archeology and genealogy as follows: "they have their theoretical coherence in the definition of the historically unique forms in which the generalities of our relations to things, to others, to ourselves, have been problematized. They have their practical coherence in the care brought to the process of putting historico-critical reflection to the test of concrete practices. I do not know whether it must be said today that the critical task still entails faith in Enlightenment; I continue to think that this task requires work on our limits, that is, a patient labor giving form to our impatience for liberty." (Ibid., 50).

65 "In the sense that it will not seek to identify the universal structures of all knowledge or of all possible moral action, but will seek to treat the instances of discourse that articulate what we think, say, and do as so many historical events." (Ibid.).

${ }^{66}$ Ibid., 51.

${ }^{67}$ Foucault, "What is Enlightenment?," 42.

${ }^{68}$ Ibid.

${ }^{69}$ Ibid. This entails rejecting what Foucault calls the "blackmail" of the Enlightenment that he associates with the critical theory of Habermas and its Hegelian derivation: "you either accept the Enlightenment and remain within the tradition of its rationalism... or else you criticize the Enlightenment and then try to escape from its principles of rationality." (Ibid., 43).

${ }^{70}$ See Ferry, Rights, 124. The sense in which the moral presupposition of a horizon of common humanity allows for the self to open itself to the selfhood of the other, is recapitulated by Alain Renaut: "[Autonomy] supposes that I am 'source of myself' only be elevating myself, as practical subject, beyond the immediacy of the empirical subject and by integrating in my ipseity the presence of the other: the subject that gives himself the law, in order to elevate himself to this auto-nomy, has had to transcend the identity to itself of the subject of inclinations (individuality) and open itself to the alterity of the human species.... this perspective, by installing intersubjectivity (in the form of what I designate as the horizon of common humanity) in the heart of subjectivity, orders, amidst the Same, the Same to the Other." (Alain Renaut, "Kant et l'humanisme," Revue de philosophie politique 2 [Paris: PUF, 1992]).

${ }^{71}$ Foucault, "What is Enlightenment?," 44.

${ }^{72}$ This point is correctly identified by Habermas: "Even if each legal subject realizes, in the role of moral person, that she herself could have given herself certain basic rights, this moral approval in hindsight will not do; it by no means eliminates the paternalism of the 'rule of law' characteristic 
of political heteronomy. It is only the participation in the practice of politically autonomous lawmaking that makes it possible for the addresees of law to have a correct understanding of the legal order as created by themselves.... The idea of self-legislation by citizens, then, should not be reduced to the moral self-legislation of individual persons.... The principle of democracy is what then confers legitimating force on the legislative process.... The principle of democracy can only appear as the heart of a system of rights." (Habermas, Between facts and norms, 121-2. Emphasis mine). This is correct as far as it goes, but Habermas does not articulate his "principle of democracy" in accordance to the two possible interpretations of the modern political situation, leaving it ambiguously underdetermined in some cases, and dangerously overdetermined in others (for example, if it is taken to apply only to "citizens" who are constituted as such only by the factual system of law).

73 "Thus far no one has succeeded in satisfactorily reconciling private and public autonomy at a fundamental conceptual level, as is evident from the unclarified relation between individual rights and public law in the field of jurisprudence, as well as from the unresolved competition between human rights and popular sovereignty in social-contract theory." (Habermas, Between facts and norms, 84).

${ }^{74}$ Michael Walzer refers to the "thick" and "thin" reconstructions of the liberal system of rights that correspond, respectively, to the two opposite senses in which "human nature" as subject of natural rights can receive a culturally predetermined interpretation. See Michael Walzer, Thick and thin: moral argument at home and abroad (Notre Dame: University of Notre Dame Press, 1984) and Charles Taylor, Multiculturalism: examining the politics of recognition (Princeton: Princeton University Press, 1994).

${ }^{75}$ Hannah Arendt, The Origins of Totalitarianism (New York: Harcourt Brace Jovanovich, 1975), 296.

${ }^{76}$ Ibid.

${ }^{77}$ Some motifs of this logic of responsibility have been lately explored in Jacques Derrida, The gift of death (Chicago: University of Chicago Press, 1995).

78 "In 1798 [in Kant's The Conflict of the Faculties/MV] Kant will offer a continuation to the text of 1784. In 1784, he tried to answer to the question that was posed to him: 'What is this Aufklärung of which we are a part?' and in 1798 he answers to a question that actuality posed him, but that had been since 1794 already formulated by the whole philosophical discussion in Germany. This question was: 'What is a revolution'." (Foucault, Dits et écrits, 4: 682).

${ }^{79}$ Kant, Political Writings, 177.

${ }^{80}$ Foucault, Dits et écrits, 683. Foucault is referring to Kant's claim that “in human affairs, there must be some experience or other which, as an event which has actually occurred, might suggest that man has the quality or power of being the cause and (since his actions are supposed to be those of a beign endowed with freedom) the author of his own improvement.... We must therefore search for an event which would indicate that such a cause exists and that it is causally active within the human race, irrespective of the time at which it might actually operate." (Kant, Political Writings, 181).

${ }^{81}$ Foucault's reading of Kant in terms of the event of freedom or republican event has a certain affinity with, and may possibly owe its inspiration to Lyotard's re-elaboration of this theme in Jean-Francois Lyotard, L'enthousiasme. La critique kantienne de l'histoire (Paris: Galilée, 1986). 
Lyotard was at work on these issues already by 1980, as can be seen from his "Introduction à une étude du politique selon Kant," in Luc Ferry ed., Rejouer le politique (Paris: Galilée, 1981). Both Lyotard and Foucault were anticipated, in this respect, by Arendt's Lectures on Kant's Political Philosophy (Chicago: University of Chicago Press, 1982), which were given at the New School for Social Research in 1970.

${ }^{82}$ See Habermas, Between facts and norms, 105-106.

${ }^{83}$ Some critics of Foucault point to the lack of an answer in his discourse to the question "why ought we to revolt?," i.e., they demand a justification for the event of freedom in terms of "reasons" or within the logical space of the redemption of validity claims. (Richard Bernstein, "Foucault: Critique as Philosophical Ethos," in Philosophical interventions in the unfinished project of the Enlightenment, eds. A. Honneth, T. McCarthy, C. Offe, A. Wellmer [Cambridge: MIT Press, 1992]: 280-310). From Foucault's perspective this demand is literally meaningless, because the possibility of raising such a validity-question, according to Kant himself, requires the event of factical freedom and therefore cannot presuppose it.

${ }^{84}$ Ibid., 686.

85 "And so on ad infinitum, until all of the past has been brought into the present in historic apocatastasis." (Walter Benjamin, Passagenwerk, N1a,3). And further: "It isn't that the past casts its light on the present or the present casts its light on the past: rather an image is that in which the past and the now flash into a constellation. In other words: image is dialectic at a standstill. For while the relation of the present to the past is purely temporal, continuous one, that of the past to the now is dialectical - isn't development but image, capable of leaping out." (Ibid., N2a,3). It is interesting that Benjamin, in describing the process of "rescuing" the past, uses the same allegorical elements of certain representations of Fortuna in the Renaissance: "Re the concept of 'rescue': the wind of the absolute in the sails of the concept. (The principle of the wind is cyclical.) The trim of the sail is the relative." (Benjamin, Passagenwerk, N9,3).

86 "Ma nelle republiche è maggiore vita, maggiore odio, piú desiderio di vendetta: né gli lascia, né può lasciare, riposare la memoria della antiqua libertà." (Machiavelli, Il Principe, V).

${ }^{87}$ Walter Benjamin, Über den Begriff der Geschichte, VII, XI, XIII.

${ }^{88}$ Walter Benjamin, Letter to Scholem, April 14, 1938, in The Correspondence of Walter Benjamin and Gershom Scholem (1932-1940), ed. G. Scholem (Cambridge: Harvard University Press, 1992). 